\title{
CURAÇAOSCHE GEGEVENS OP ECONOMISCH GEBIED
}

\author{
DOOR
}

\author{
W. R. MENKMAN
}

Sommige Westindische publicaties bereiken ons met groote vertraging. Zoo beschikken wij eerst thans over het Jaavverslag van de Kamer van Koophandel en Nijverheid op Curaçao over de jaren 1942 en 1943, in Augustus 1944 te Willemstad verschenen.

Het eerste hoofdstuk behandelt de huishoudelijke aangelegenheden der Kamer, het tweede geeft verslag van haar werkzaamheden.

Zooals van zelf spreekt had de Kamer in de oorlogsjaren veelvuldig contact met het gouvernement, in verband met allerlei overheidsmaatregelen, door de tijdsomstandigheden vereischt. Wij lezen ook dat de Handel zich kon vereenigen met een plan om de klok één uur vooruit te zetten, in het belang van een economisch gebruik van het daglicht in de na zonsondergang verduisterde stad, terwijl het oliebedrijf het gewenscht bleek te achten dat de Benedenwindsche eilanden denzelfden tijd zouden hebben als westelijk Venezuela, met het oog op de vaart der tankschepen op Maracaibo.

Zeer belangrijk lijkt het advies, door de Kamer uitgebracht, betreffende het ontwerp eener landsverordening houdende regelen nopens de burgerrechtelijke aanspraken ten gevolge van ongevallen met of door motorrijtuigen - en wat daarmede in verband stond.

Een nijpend tekort aan pasmunt op Curaçao noopte de Kamer er toe bij het gouvernement aan te dringen op het in omloop brengen van hetgeen er nog in reserve gehouden werd, wat echter op het bezwaar bleek te stuiten dat op de uitvoering eener in de V.S. geplaatste bestelling gewacht werd, zoodat voorzichtigheid geboden leek. Intusschen is uit het Curaçaosch Verslag 1945, t.w. het op Curaçao zelf samengestelde en door middel van den cyclostyle vermenigvuldigde, gebleken dat in 1944 voor een bedrag van 330.000 gulden aan Curaçaosche munt in de V.S. geslagen, in omloop gebracht werd; hierin zal wel pasmunt begrepen geweest zijn.

Een vraag, in 1943 door de inspectie van het Onderwijs tot de Kamer gericht, of de Curaçaosche Handel het voorbeeld van het gouvernement zou volgen, wanneer dit de spelling-Marchant zou aanvaarden, werd in afwijzenden zin beantwoord.

In behandeling bij de Kamer was nog steeds het geschil tusschen den Handel en de petroleum-maatschappij, ter zake van de commissariaatsplannen (eigen winkelnering van het bedrijf).

Ter zake van het vaststellen van maximumprijzen van niet-alcoholische dranken, in café's verkocht, bleef de Kamer het standpunt innemen dat in het algemeen zoodanige prijzen slechts behooren te gelden voor den verkoop van noodzakelijke levensbehoeften. 
Na de opsomming der wel zeer uiteenloopende aangelegenheden waarmede de Kamer in de verslag-periode bemoeiïngen gehad had, volgt in het derde hoofdstuk een overzicht van den economischen toestand van het eiland Curaçao in 1942 en 1943.

Deze toestand wordt als in het algemeen bevredigend beschreven, behoudens de moeilijkheden, inhaerent aan de oorlogs-omstandigheden, als daar waren tekort aan scheepsruimte, te gering aanbod van arbeidskrachten, langdurig oponthoud bij leveringen uit het buitenland enz.

Hoe belangrijk Curaçao voor de oorlogvoering was kan hieruit blijken, dat alle technische benoodigheden der oliebedrijven regelrecht door de War Petroleum Administration in de V.S. geleverd werden.

De V.S. en Engeland trokken zich bij onderlinge overeenkomst de geheele overige goederenvoorziening, niet alleen van Curaçao, maar van geheel Nederlandsch West Indië aan. Veel dat vroeger uit Noord Amerika geïmporteerd werd echter moest nu uit Argentinië en Brazilië betrokken worden; het inter-Caraibische verkeer werd geheel van de zeilvaart afhankelijk.

Voor de jaren 1941, 1942 en 1943 vinden wij de waarde van den invoer op Curaçao aangegeven met resp. ruim $26 \frac{3}{4}$, ruim $24 \frac{1}{2}$ en bijna 36 millioen gulden, waarin niet begrepen de ,,aardolieproducten"; waarschijnlijk worden onder deze laatste benaming verstaan in de eerste plaats ruwe olie en verder de verschillende derivaten en residu, afkomstig van elders gevestigde raffinaderijbedrijven. Afzonderlijk wordt genoemd de waarde der ten behoeve van de Curaçaosche petroleumindustrie ingevoerde materialer, zijnde resp. ruim 5 , ruim $19 \frac{1}{2}$ en ruim $21 \frac{1}{4}$ millioen gulden, blijkbaar niet begrepen in de hooger genoemde totaalcijfers.

$\mathrm{Bij}$ de gespecificeerde invoerlijst wordt aangeteekend dat invoercijfers van ,,aardolieproducten" niet vermeld mochten worden.

De uitvoertabellen geven voor 1942 en 1943 totalen aan van resp. nog geen $1 \frac{3}{4}$ en bijna $1 \frac{1}{2}$ millioen gulden, zonder ,, aardolieproducten".

Twee andere staten ten slotte specificeeren den invoer voor 1942 en 1943 naar de landen van herkomst, totaal resp. ruim 44 en ruim $64 \frac{1}{4}$ millioen gulden, zonder ,,aardolieproducten”, maar blijkbaar met inbegrip van de ,,materialen" voor het petroleumbedrijf; voor 1943 is het totaal belangrijk hooger dan men verwachten zou (bijna 36 millioen plus ruim $21 \frac{1}{4}$ millioen geeft ongeveer 57 millioen). In beide jaren staan het Britsche Imperium, de V. S. - plus territories - en de Rep. Argentinië bovenaan; de invoer uit Nederland was uit den aard der zaak onbeteekenend.

De doorvoer via het eiland Curaçao beliep in 1942 nog 107.250 ton (à 1000 K.G.), doch in 1943 nog geen 66.000 ton. Hoewel vermeld wordt dat doorvoercijfers betreffende ,, aardolieproducten" niet gepubliceerd mochten worden, geeft de staat voor 1942 nog ruim 41.000 ton gasolie en ruim 2300 ton gasoline.

Het reeds genoemde Curaçaosche Verslag licht ons, met betrekking tot het jaar 1944, als volgt in:

$a$. invoerwaarde eiland Curaçao bijna 176 millioen gulden, waarin begrepen ,,aardolieproducten" ruim 118 millioen en niet nader omschreven goederen bijna $29 \frac{1}{2}$ millioen; voor het eiland Aruba waren de cijfers resp. ruim 208 millioen, ongeveer $174 \frac{3}{4}$ millioen en ruim 21 millioen, voor het geheele gebiedsdeel ruim 385 millioen, bijna 293 millioen en bijna 51 millioen gulden. 
$b$. uitvoerwaarde eiland Curaçao ruim 135 millioen gulden, waarin begrepen ruim 131 millioen aan ,'Olieproducten"; voor het eiland Aruba waren de cijfers resp. ruim 162 en bijna 160 millioen, voor het geheele gebiedsdeel bijna $297 \frac{1}{2}$ millioen en ruim 291 millioen gulden.

c. voornaamste landen van herkomst der ingevoerde goederen: Venezuela circa $195 \frac{1}{2}$ millioen, Ver. Staten en territories circa $163 \frac{1}{2}$ millioen, Br. imperium $10 \frac{1}{4}$ millioen gulden; Suriname een klein bedrag, Nederland nihil.

d. van den export van het geheele gebiedsdeel werd voor een waarde van bijna 273 millioen met onbekende bestemming uitgevoerd en voor een waarde van bijna $19 \frac{1}{2}$ millioen aan schepen geleverd, zoodat iets meer dan 5 millioen gulden door met namen genoemde landen afgenomen werd, hoofdzakelijk de V.S. en Venezuela.

Wat den financieelen toestand betreft leert het Verslag van de Kamer van Koophandel ons dat, volgens voorloopige begrootingen en ramingen, de cijfers der uitgaven en inkomsten van het geheele gebiedsdeel zich in 1942 bewogen om de 19 en in 1943 om de $26 \frac{1}{2}$ mililoen gulden. Volgens het Curaçaosche Verslag 1945 werden voor 1944 de uitgaven begroot op ruim 26 millioen en de inkomsten geraamd op iets meer; de opbrengst der middelen echter zou hebben bedragen : voor den gewonen dienst bijna $28 \frac{1}{4}$ millioen en voor den kapitaaldienst ruim 4 millioen gulden.

Aan de burgerlijke openbare werken, zegt de Kamer van Koophandel, kon in 1942 en 1943 weinig gedaan worden, omdat de militaire voorzieningen alle krachten opeischten; voor 1944 is de toestand, volgens het meergenoemde verslag, blijkbaar niet in belangrijke mate veranderd.

Aan phosphaat werd van Curaçao in 1942 nog een kleine hoeveelheid uitgevoerd, in 1943 bijna niets meer; hieraan kan nu, aan de hand van het Curaçaosche Verslag, worden toegevoegd dat in 1939 uitgevoerd werd ruim 64.000 ton, in 1941 bijna 112.000 ton - en dat de uitvoercijfers van 1940,1943 en 1944 onbeteekenend waren.

De zoutwinning zou, volgens de Kamer van Koophandel, in 1942 en 1943 een bloeiperiode beleefd hebben en cijfers worden gegeven betreffende den uitvoer van de gezamenlijke zoutproduceerende Nederlandsche Antillen; voor 1944 vinden wij nu eenige gegevens betreffende productie en uitvoer van Bonaire en Sint Maarten.

Beleefden in 1942 en 1943 de kleine plaatselijke industrieën in het algemeen een goeden tijd, van 1944 kan blijkbaar hetzelfde gezegd worden. De aloude hoedenvlechterij evenwel heeft weinig meer te beteekenen.

De handel ondervond in 1942 en 1943 nog meer belemmeringen dan in de voorafgegane oorlogsjaren; desniettemin waren de resultaten voor de kooplieden ter plaatse toch gunstig. Voor 1944 geldt dit laatste blijkbaar eveneens, niettegenstaande de onvrijheid, door reglementeering en andere ongunstige factoren.

Wat de scheepvaart betreft vermeldt de Kamer van Koophandel groote veranderingen in 1942 en 1943, wegens duikbootgevaar en noodzaak van convooi. De lijnvaart verminderde, doch de tankvaart nam sterk toe en de zeilvaart bloeide. In het gunstige jaar 1938 werd het eiland Curaçao bezocht door 6872 stoom- en motorschepen, met een totalen netto inhoud van 41.635 .399 cub.M.; deze cijfers liepen in 1942 terug tot resp. 3210 en 20.150.476, doch klommen in 1943 weder tot resp. 3863 en 41.443.855. Uit het Cur. Versl. kan hieraan toegevoegd worden: 
a) aangekomen in 1944 op Curaçao 4144 stoom- en motorschepen, met een totalen bruto inhoud van 48.954 .149 cub.M.

b) aangekomen in 1944 op Aruba 5402 stoom- en motorschepen, met een totalen bruto inhoud van 96.818 .553 cub.M.

Het aantal zeilschepen dat op Curaçao aankwam was in 1943 slechts 723, tegen 1974 in 1942, 1819 in 1940 en 1822 in 1937; in 1944 bedroeg het 2378. Op Aruba kwamen in 19441273 zeilvaartuigen binnen. De gouden tijd was voor de zeilvaart in 1944 voorbij, wegens afschaffing van het convooisysteem, waardoor de stoomvaart meer vrijheid van beweging kreeg.

Touristenschepen lieten zich uit den aard der zaak gedurende de oorlogsjaren niet zien. Het aantal aangekomen, vertrokken en transitopassagiers op Curaçao bedroeg in 1942 resp. 17.187, 15.409 en 6183, in 1943 resp. $20.270,19.545$ en 4361 , in 1944 resp. 25.627, 23.211 en 10.392 . Wat het jaar 1942 betreft komen de cijfers in het Verslag van de Kamer van Koophandel niet met die in het Curą̧asche Verslag overeen.

Waarschijnlijk hebben de genoemde cijfers alleen betrekking op scheepspassagiers; immers de K.L.M. vervoerde in 194225.117 passagiers, in 194333.152 en in 194433.741 ; uit de verdere gegevens echter schijnt wel te concludeeren te zijn dat het hier de totale aantallen op de rondvluchten geldt. De P.A.A. nam in 1944 (sedert begin Februari) mede 1996 passagiers, naar Laguaira, de Dom. Republiek, Haiti, Cuba en Miami; bovendien werden op de lijn Miami-Laguaira-Miami, heen en terug via Curaçao (sedert 1 April 1944 dagelijksche dienst), 7206 transitopassagiers vervoerd.

Een tekort aan arbeidskrachten kon in 1942 en 1943, doch ook nog in 1944, geconstateerd worden, als gevolg vooral van het onder de wapenen houden van dienstplichtigen. De in 1943 ingevoerde arbeidsplicht-verordening behoefde evenwel niet toegepast te worden; zelfs konden in 1944 een aantal bedrijven afgevoerd worden van de lijst der overheids- en particuliere instellingen waarin verplichte arbeid verricht zou moeten worden.

Wat het bankwezen betreft kunnen wij beschikken over gegevens aangaande de circulatiebank en twee der drie particuliere bankinstellingen op Curaçao; alles over de jaren 1942,1943 en 1944.

De billettencirculatie liep op van $f 18.634 .812$ in 1942 tot $f$ 29.422.822 in 1944, alles per 31 December. De metaaldekking was steeds begrepen in de kassaldi op de balansen.

De depositorekeningen van de Curaçaosche Bank en de twee particuliere banken gaven een gezamenlijk saldo verschuldigd aan van bijna 42 millioen op het eind van 1942, ruim 57 millioen op het eind van 1943 en bijna 73 millioen op het eind van 1944 .

Het tegoed der inleggers bij de Curaçaosche Postspaarbank steeg van nog geen $1 \frac{3}{4}$ millioen op 31 December 1942 tot ruim 4 millioen op 31 December 1944. De instelling werkte met verlies, wegens gebrek aan beleggingsmogelijkheden en relatief te hooge rente, aan de inleggers verschuldigd; de rentevoet werd dan ook in 1944 sterk verlaagd. Andere banken op Curaçao vergoedden heelemaal geen rente, evenmin trouwens als die in Nederland.

De Spaar- en Beleenbank op Curaçao bleef ook gelden in deposito aannemen; het bedrag bleef in de jaren 1942-1944 steeds beneden het millioen; het totaal der hypotheken, bij de Curaçaosche Hypotheekbank 
ondergebracht, bewoog zich gedurende dezelfde periode om de $1 \frac{1}{2}$ millioen gulden.

Al de hierboven genoemde instellingen - met uitzondering misschien van de Spaar- en Beleenbank - kunnen geacht worden de gezamenlijke Nederlandsche Antillen tot arbeidsterrein te hebben. Er is echter ook bekend een balans van de N.V. Aruba Bank, gevestigd te Oranjestad, wier depositorekening op 30 Juni 1944 een saldo aangaf van bijna $6 \frac{1}{2}$ millioen gulden. Er wordt aangeteekend dat, vergeleken bij 1939, het bedrag der depositos verdrievoudigd was - en dat, ondanks het beleggingsprobleem, nog altijd rente aan depositarissen vergoed werd.

Ten slotte kreeg schrijver nog de beschikking over een op Curaçao samengesteld en niet gedrukt verslag, waarin de onderstaande economische gegevens betreffende het jaar 1945 .

Scheepvaart:

Aangekomen op Curaçao 5166 stoom- en motorschepen, met een gez. bruto inhoud van $63.931 .068 \mathrm{cub} . \mathrm{M}$.

Aangekomen op Aruba 5669 stoom- en motorschepen, met een gez. bruto inhoud van 69.861 .037 cub.M.

Invoer:

Waarde invoer eiland Curaçao ongeveer 2081 millioen gulden, waaronder ,,aardolieproducten” ruim 159 millioen en niet gerubriceerde goederen ruim 20 millioen.

Waarde invoer eiland Aruba ruim 264 millioen gulden, waaronder ,,aardolieproducten” ruim 219 millioen en niet gerubriceerde goederen bijna $30 \frac{1}{4}$ millioen.

Uitvoer:

Waarde uitvoer eiland Curaçao ruim 186 millioen gulden, waaronder ruim $162 \frac{1}{4}$ millioen aan ,,aardolieproducten" en ruim $2 \frac{1}{2}$ millioen aan niet gerubriceerde goederen.

Waarde uitvoer eiland Aruba bijna $274 \frac{1}{2}$ millioen gulden, waaronder bijna 272 millioen aan ,,aardolieproducten" en ruim $1 \frac{1}{2}$ millioen aan niet gerubriceerde goederen.

Doorvoer met overlading:

Op Curaçao bijna 57.500 ton, waaronder 390 ton ,,olieproducten”.

Op Aruba bijna 475 ton, geen ,olieproducten”.

De overlading van ,olieproducten" is op Curaçao begonnen in 1939, grootste hoeveelheid ruim 44.000 ton in 1942 .

Op Aruba hield deze soort overlading op met het jaar 1943, grootste hoeveelheid bijna 585.000 ton in 1920 .

De cijfers der overlading zijn in tonnen van 1000 K,G.

De bevolkingssterkte op 31 December 1945 zou voor de zes Ned. Antillen te zamen statistisch gesteld zijn op 133.799, maar met 7000 verhoogd kunnen worden, wegens tijdelijk aanwezige arbeidskrachten voor de oliebedrijven op Curaçao en Aruba.

Voor 1946 verwacht men een aanwas van circa 5000 zielen.

De cijfers der inkomsten en uitgaven vinden wij voor 1945 gesteld op ongeveer $29 \frac{1}{2}$ millioen, voor 1946 op circa $34 \frac{1}{2}$ millioen en voor 1947 op omstreeks 30 millioen, in het laatste geval evenwel zonder dat met supletoire begrootingen rekening gehouden kon worden.

Juli 1947. 